\title{
DEUTERIUM, TRITIUM, AND $\beta$ ACTIVITY IN A SNOW CORE TAKEN ON THE SUMMIT OF MONT BLANC (FRENCH ALPS). DETERMINATION OF THE AGGUMULATION RATE
}

\author{
By J. Jouzel, L. Merlivat
}

(Departement de Recherche et Analyse, Centre d'Études Nucléaire de Saclay, Boîte Postale No. 2, 91 190 Gif-sur-Yvette, France)

and M. Pourchet

(Laboratoire de Glaciologie du CNRS, Boîte Postale No. 53, 3804I Grenoble Cedex, France)

\begin{abstract}
Deuterium, tritium, and gross $\beta$ activity measurements have been performed to a depth of $16 \mathrm{~m}$ on a snow core taken on Mont Blanc (French Alps) to establish a chronology of its formation and then deduce the annual accumulation. These three independent methods show that the core was formed over a three-year period. This corresponds to a mean annual accumulation of $2.8 \mathrm{~m}$ water equivalent In addition, the isotopic measurements indicate the existence of an altitude effect in the distribution of deuterium and tritium in the precipitation in the Mont Blanc area.

RÉsumÉ Analyse des teneurs en deuterium et tritium et de l'activité $\beta$ dans une carotte de neige prélevée au sommet du Mont Blanc (Alpes Françaises). Détermination du taux d'accumulation. Des mesures de deutérium, de tritium et d'activité $\beta$ globale ont été effectuées dans une carotte de neige d'une longueur de $16 \mathrm{~m}$ prélevée au somme du Mont Blanc (Alpes Françaises) dans le but d'établir la chronologie de sa formation et d'en déduire l'accumulation annuelle. Ces trois méthodes indépendantes montrent que cette carotte s'est formée en trois ans ce qui correspond à une accumulation moyenne annuelle de $2,8 \mathrm{~m}$ d'eau. En outre, les mesures de deuterium et de tritium indiquent l'existence d'un effet d'altitude sur la teneur de ces isotopes dans les précipitations dans la région du Mont Blanc.

Zusammenfassung. Deuterium, Tritium und $\beta$-Aktivität in einem Schneebohrkern vom Gipfel des Mont Blanc (Französische Alpen). Bestimmung der Akkumulationsrate. Messungen von Deuterium und Tritium sowie der Gesamt- $\beta$-Aktivität bis zu einer Tiefe von $16 \mathrm{~m}$ wurden an einem Schneebohrkern vom Gipfel des Mont Blanc (Französische Alpen) vorgenommen, um eine Chronologie seiner Entstehung zu gewinnen und daraus die jährliche Zuwachsrate herzuleiten. Diese drei unabhängigen Methoden zeigen, dass der Bohrkern innerhalb von drei Jahren gebildet wurde. Dies entspricht einer mittleren jährlichen Zuwachsrate von 2,8 $\mathrm{m}$ Wasserwert. Daneben deuten die Deuterium- und Tritium-Messungen auf das Vorhandensein eines Höheneffekts für die Verteilung dieser Isotope im Niederschlag des Mont Blanc-Gebietes hin.
\end{abstract}

\section{INTRODUCTION}

Deuterium, tritium, and gross $\beta$ activity measurements were performed on a $16 \mathrm{~m}$ snow core taken on Mont Blanc on i9 June 1973. The sampling station was located about $170 \mathrm{~m}$ east of the summit at an altitude of $4785 \mathrm{~m}$ a.s.l.

The aim of these determinations is to establish a chronology for the formation of this core based on the seasonal variations of deuterium, tritium, and gross $\beta$ activity in the precipitation, and then to deduce the annual accumulation. The application of these isotopic techniques implies that accumulation occurs both in summer and winter and that no important melting and precipitation take place. Meteorological data show that these two conditions are fulfilled on Mont Blanc. In particular, air temperature is nearly always below $0^{\circ} \mathrm{C}$. Transport and deposition of snow by the wind cannot be ruled out but we can anticipate that these phenomena should not affect the snow-layer chronology as the sampling point is located on a small plateau to the east of the summit which is well protected from the prevailing westerly winds.

\section{EXPERIMENTAL RESULTS}

The snow core was cut into 154 samples. The firn density varies between 0.4 and $0.6 \mathrm{Mg} / \mathrm{m}^{3}$. Deuterium and gross $\beta$ activity were measured on all the samples. Tritium was analysed on I 36 samples, the amount of water available for the remaining 18 samples being too small for our analytical procedure. 
Figures $\mathrm{I}$ to 3 represent the deuterium and tritium contents and the gross $\beta$ activity measured on each sample versus snow depth. The data are expressed in $\delta \mathrm{D}$ in parts per thousand $(\%)$ compared with standard mean ocean water (S.M.O.W.) for deuterium, in tritium units (T.U.) calculated at the sampling date for tritium, and in disintegrations per hour and per kilogramme of water (d.p.h./ $/ \mathrm{kg}$ ) calculated at the counting date for the gross $\beta$ activity. Experimental errors (one standard deviation) are estimated as equal to $0.2 \%$ for deuterium, between 15 and 30 T.U. for tritium, and $10 \%$ for gross $\beta$ activity.

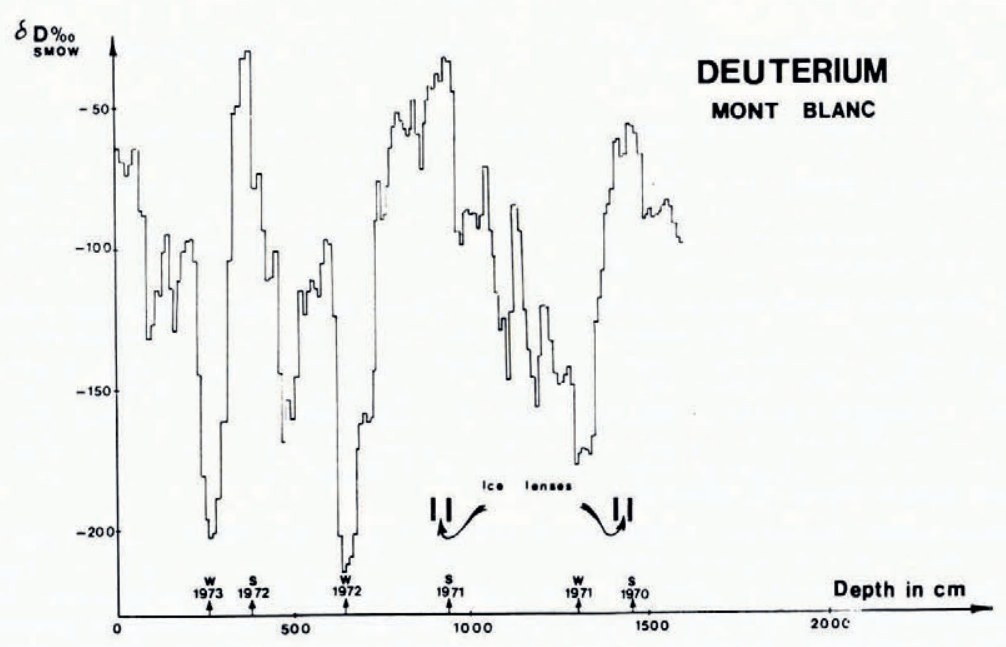

Fig. I. Deuterium profile with the depth of snow.

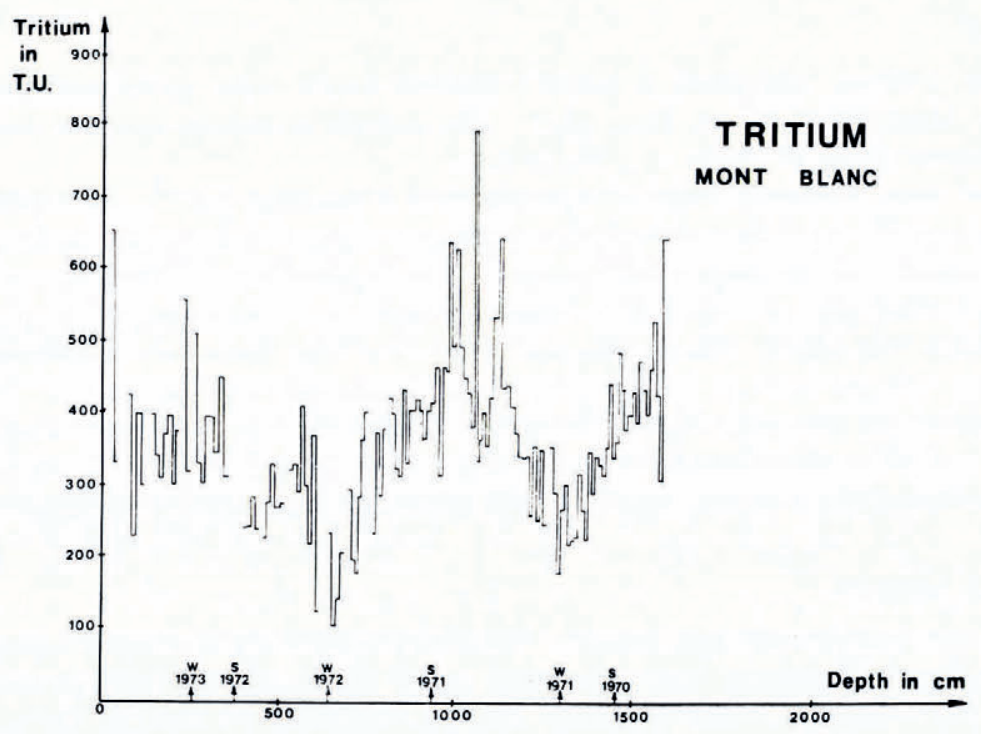

Fig. 2. Tritium profile with the depth of snow. 


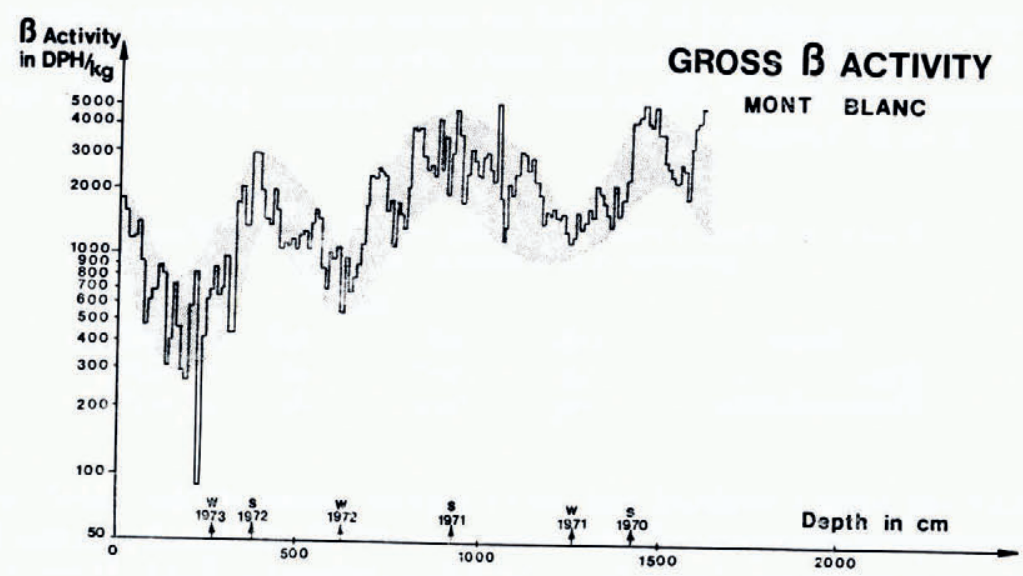

Fig. 3. $\beta$ activity profile with the depth of snow.

\section{SNOW-GORE GHRONOLOGY}

\section{Deuterium}

Annual variations of the deuterium content in the precipitation are characterized by high values in summer and low values in winter (International Atomic Energy Agency (IAEA), 1973, 1975). The deuterium profile in the investigated snow core (Fig. I) shows four main regions of high content at surface level and at depths of around $3.7 \mathrm{~m}, 9.4 \mathrm{~m}$ and $14.4 \mathrm{~m}$ and three main sections with low content at depths of around $2.7 \mathrm{~m}, 6.3 \mathrm{~m}$ and $12.9 \mathrm{~m}$. The surface maximum corresponds to the beginning of summer 1973 and the underlying extrema can be respectively attributed to 1973 winter, 1972 summer and winter, I97 I summer and winter and 1970 summer. This chronology is reported on the three Figures $1_{1} 2$ and 3 , where $\mathrm{W}$ and $\mathrm{S}$ are written for winter and summer respectively.

Ice lenses are observed at $9.1 \mathrm{~m}$ and $\mathrm{I} 4.2 \mathrm{~m}$ in the core (Fig. I). These depths correspond to zones of high deuterium content. As ice is formed only in summer and without percolation, since the temperature is low in the snow mantle $\left(-20^{\circ} \mathrm{C}\right)$, its presence confirms the attribution of these two zones to summer snow as deduced from the deuterium measurements.

Secondary oscillations appear in the deuterium profile, one of which, with a minimum at $4.7 \mathrm{~m}$ and a maximum at $5.8 \mathrm{~m}$, is important. Thus it appears necessary to investigate the tritium and the gross $\beta$ activity profiles to check if this oscillation, which has an amplitude equal to $40 \%$ of that between the two extremes, does not correspond to a supplementary year.

\section{Tritium}

An annual tritium concentration peak in the precipitation is observed in the late winter, the spring, or the early summer, generally between March and June in the northern hemisphere (IAEA, I973, I975) as the result of a stratospheric-tropospheric exchange, any important contribution from nuclear power plants being excluded.

Figure 2 shows two zones of high tritium values at depths between $9.9 \mathrm{~m}$ and I I. $3 \mathrm{~m}$ for the first and $14.4 \mathrm{~m}$ and $16 \mathrm{~m}$ for the second. These sections should correspond to the springs 1971 and 1970 if we accept the first chronology deduced from the deuterium profile (Fig. I) and to the springs 1970 and 1969 if we suppose that the deuterium oscillation between $4.7 \mathrm{~m}$ and $5.8 \mathrm{~m}$ adds a supplementary year.

To decide between these two hypotheses we have compared the tritium values in the snow core with those measured at the nearest stations where tritium precipitation data are available. 
For this purpose, we have reported in Table I the mean annual weighted value of the tritium content measured in precipitation during the years 1969 to 1972 at Thonon-les-Bains (France) (personal communication from P. Olive) and at Wien (Austria) (IAEA, 1973, r975; personal communication from R. Gonfiantini).

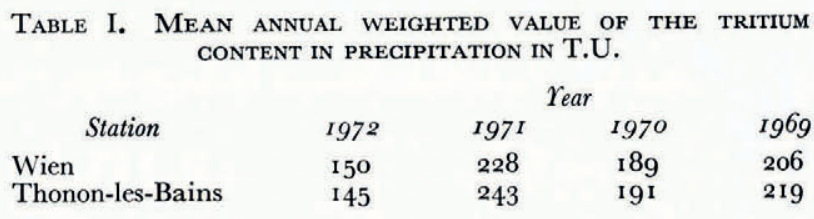

Furthermore we have calculated the mean tritium values in the snow core between successive winter layers, the depths of which were deduced from deuterium chronology based on each of the two assumptions (Table II). The values reported in Table II are those relative to the date of precipitation.

Table II. Mean tritium contents in the snow core in T.U.

\section{Period}

Winter 1973 to winter 1972

Winter 1972 to winter 1971

Winter 1971 to winter 1970

\section{Corresponding year}

I 972

I 971

1970

\begin{tabular}{|c|c|}
\hline \multicolumn{2}{|c|}{ First assumption } \\
\hline $\begin{array}{l}\text { Depths } \\
\text { m }\end{array}$ & $\begin{array}{c}\text { Mean tritium values } \\
\text { T.U. }\end{array}$ \\
\hline $2.7-6.3$ & $3^{24}$ \\
\hline $\begin{array}{c}6.3^{-12.9} \\
\text { not entire }\end{array}$ & $\begin{array}{c}42 \mathrm{I} \\
\text { oresent in the }\end{array}$ \\
\hline
\end{tabular}

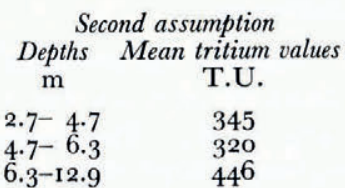

The period between two successive winters corresponds approximately to one entire year which is indicated in Table II. On the first assumption, the ratio between the I97 I and the I 972 tritium contents in the snow is equal to 1.3 (Table II) and agrees reasonably well with the Thonon-les-Bains and the Wien data where the average value of this ratio in the precipitation is equal to r.6 (Table I). On the second assumption, the tritium concentration in the snow core and the precipitation during 1970, I97 I and 1972 are in complete disagreement (Tables I and II). This shows that tritium peaks around $10 \mathrm{~m}$ and $\mathrm{I} 5 \mathrm{~m}$ must be due respectively to the $197 \mathrm{I}$ and 1970 snow precipitation, thus confirming the first chronology deduced from the deuterium profile.

\section{Gross $\beta$ activity}

The gross $\beta$ activity in the precipitation shows an annual peak which originates, as for tritium, in a stratospheric-tropospheric exchange. In France, this peak is observed in the early summer (personal communication from J. C. Philippot), i.e. at the same period as the deuterium maximum.

Figure 3 shows three main oscillations which correspond to three successive years and entirely confirm the first deuterium chronology. Moreover, the relative values of 1970, I97 I and 1972 gross $\beta$ activity are in agreement with the gross $\beta$ activity data measured in France during these years (personal communication from J. C. Philippot). This information obtained from a detailed $\beta$ activity profile does not confirm the value of 12 years of accumulation deduced by Lliboutry and others (1976) from preliminary $\beta$ activity measurements carried out on this core.

We have no indication to relate the individual peaks which appear each year in the firn with the Chinese bomb tests performed during the period. 


\section{Determination of the aGgumulation Rate}

Using the above results, we have calculated the mean annual snow accumulation at the top of the Mont Blanc along the core. Its value is equivalent to $2.8 \mathrm{~m}$ of water.

Annual amounts of precipitation have been measured at different stations in the Mont Blanc area at various altitudes between $1050 \mathrm{~m}$ and $3160 \mathrm{~m}$ (Voiron, unpublished). These measurements show that the mean annual amount of precipitation increases linearly with altitude. The extrapolation of this relationship to the altitude of Mont Blanc provides an estimate of the mean annual precipitation at this point equal to $2.9 \mathrm{~m}$. This value is very close to the mean annual accumulation between the spring 1970 and June $1973(2.8 \mathrm{~m})$ estimated from the above results. This close agreement tends to show that overall wind effects on transport and deposition at the sampling point are negligible.

\section{COMPARISON OF ISOTOPE GONTENTS IN THE SNOW CORE WITH THOSE IN PRECIPITATION}

A continuous record of ${ }^{18} \mathrm{O}$ and tritium data in precipitation is available at the Thononles-Bains sampling station (personal communication from P. Olive) located $68 \mathrm{~km}$ to the north of Mont Blanc and at an altitude of $385 \mathrm{~m}$. To check the existence of an isotopic altitude effect, we have tentatively tried to compare the Thonon-les-Bains and Mont Blanc mean isotopic values for the same periods notwithstanding that isotopic contents in the precipitation at Thonon-les-Bains station and the Mont Blanc valley may be slightly different due to their geographical locations.

The mean weighted value of ${ }^{18} \mathrm{O}$ content in the Thonon-les-Bains precipitation between spring 1970 and June 1973 is equal to $-9.46 \% /$ S.M.O.W. The mean ${ }^{18} \mathrm{O}$ content in the snow core during the same period is deduced from the relation $\delta \mathrm{D}=8 \delta^{18} \mathrm{O}+\mathrm{IO}$ (Craig, I96I) and is equal to $-\mathrm{I} 4.6 \% /$ S.M.O.W. This would correspond to a mean altitude effect of $-0.12 \% / 100 \mathrm{~m}\left(\right.$ for ${ }^{18} \mathrm{O}$ ) between Thonon-les-Bains and the summit of Mont Blanc. This rough estimate is lower than that quoted by Ambach and others (1968) in the Innsbruck area $(-0.2 \% / 100 \mathrm{~m})$. Isotopic modifications due to exchange or evaporation are certainly strongly reduced when the condensed water is in the solid state. This probably leads to a decrease in the apparent altitude effect at high altitudes where precipitation is generally in the solid phase and may explain the small value of mean altitude effect between Thonon-les-Bains and the Mont Blanc summit compared with the value observed between lower altitudes ( 580 to $2260 \mathrm{~m})$ in the Innsbruck area.

The tritium content in the Mont Blanc snow is 2.2 times higher than in Thonon-les-Bains precipitation for the period extending from winter 1971 to June 1973. Thus, we consider that the increase of tritium content at Mont Blanc shows an altitude effect which probably results from two mechanisms. First, the clouds which give snow on Mont Blanc may penetrate higher layers of the troposphere than those providing the precipitation in Thonon-les-Bains and consequently pick up enriched tritium moisture. Secondly, isotopic exchange between liquid water and lower tritium-content vapour in the low tropospheric layers may decrease the tritium concentration in the Thonon-les-Bains precipitation. Isotopic measurements at a middle-altitude station would probably allow us to assess the relative contribution of these two processes.

\section{Acknowledgements}

We are very grateful to G. Mondet and D. Mazaudier for their experimental assistance and to C. Lorius for his comments.

MS. received ${ }_{15}$ October 1976 and in revised form 8 March 1977 


\section{REFERENGES}

Ambach, W., and others. 1968. The altitude effect on the isotopic composition of precipitation and glacier ice in the Alps, by W. Ambach, W. Dansgaard, H. Eisner and J. Møller. Tellus, Vol. 20, No. 4, p. 595-60o.

Craig, H. 196I. Isotopic composition in meteoric waters. Science, Vol. 133, No. 3465, p. 1702-03.

International Atomic Energy Agency (IAEA). 1973. Environmental isotope data, No. 4. Technical Report Series, No. 147.

International Atomic Energy Agency (IAEA). 1975. Environmental isotope data, No. 5. Technical Report Series, No. 165 .

Lliboutry, L. A., and others. 1976. $15 \mathrm{~m}$ deep temperatures in the glaciers of Mont Blanc (French Alps), by L. A. Lliboutry, M. Briat, M. Creseveur and M. Pourchet. Fournal of Glaciology, Vol. 16, No. 74, p. 197-204.

Voiron, H. Unpublished. Précipitation en haute montagne. [In Bulletin climatique mensuel de la Haute-Savoie, décembre i973.] 